\title{
DEVELOPMENT OF FINANCIAL DECENTRALIZATION AS A BASIS FOR SELF-SUFFICIENCY OF TERRITORIAL COMMUNITIES
}

\author{
Tetiana Stroiko ${ }^{\text {, Natalia Danik², Dmytro Prokofyev }}{ }^{3}$
}

\begin{abstract}
The purpose of this article is to analyze the achieved results in the process of financial decentralization in Ukraine, with the further improvement of the methodology of its implementation for increasing the efficiency in the system of financial security of local budgets. Methodology. For the purpose of substantiation of directions of financial decentralization development in conditions of hromadas self-sufficiency the following modern methods of research are used: historical, dialectical method of knowledge, system analysis, abstractedly-logical, graphic, statistical. The object of the study is the processes of development of financial decentralization through the prism of self-sufficiency of hromadas. The theoretical basis of this research is the fundamental provisions of economic theory, national economy, state and regional administration, and theory of local finance. Results. It has been proved that the most effective option is when the population residing in a particular territory takes part in the implementation of management functions in the region, which requires significant financial resources to ensure the implementation of management responsibilities. It is for this purpose that the process of decentralization, which is a complex and multi-component process connected with fiscal decentralization, was initiated in Ukraine. It has been substantiated that for further effective reform it is necessary to solve the issue of changes in the Constitution of Ukraine, as well as in the administrative organization of the country. Practical implications. It is determined that the keynote of fiscal decentralization is the principle of fiscal equivalence, when the efficiency of a particular hromada is achieved through such a mechanism of formation of revenues to local budgets that the end consumer of public goods at the local level will be financially responsible for expenses, as well as their order, volume and priority, within the limits of taxes transferred to them. The tax system bottlenecks of personal income were identified. It has been proven that the more freedom in setting the rates of local taxes and fees is given to local governments, the more there is an opportunity to set them at a level that will be suggested by local residents, because the hromada will demand at a high level of taxation a proper quality provision for their vital needs and, in addition, local government accountability.
\end{abstract}

Key words: fiscal decentralization, taxes, fees, fiscal reform, amalgamated territorial community, budget, local authorities.

JEL Classification: H71, H76, M48, R51

\section{Introduction}

Ukraine today is a country that is a hostage of unpopular decisions made by the authorities concerning the standard of living of every citizen. And this ordinary citizen, according to the Constitution of Ukraine, has the right to a decent life, which means social security, clean streets with full lighting and convenient road interchanges, quality education, as well as modern medicine. But the population does not feel that the authorities treat their vital needs with decency, and the main reason for this is that such structures are isolated from the realities of society.

\footnotetext{
Corresponding author:

${ }^{1}$ V.O. Sukhomlynskyi Mykolaiv National University, Ukraine.

E-mail: tanyastroyko@gmail.com

ORCID: https://orcid.org/0000-0002-0044-4651

ResearcherID: AAB-2925-2021

${ }^{2}$ V.O. Sukhomlynskyi Mykolaiv National University, Ukraine.

E-mail: natasha.danik29@gmail.com

ORCID: https://orcid.org/0000-0001-5821-6232

${ }^{3}$ V.O. Sukhomlynskyi Mykolaiv National University, Ukraine.

E-mail: dprokofyev42@gmail.com

ORCID: https://orcid.org/0000-0001-6055-2307
} 
Like any other phenomenon, decentralization has many advantages and disadvantages. The most significant advantages of regional decentralization, as well as increased self-sufficiency of hromadas, are the creation of a basis for the development of civil society. After all, the main task of decentralization is to form a democratic field in which hromada residents will gain practical experience of co-participation in addressing the vital needs of their hromadas, contributing to their development and level of responsibility. The negative aspects of decentralization include complicating the process of implementing strategic state programs and giving priority to regional political elites.

Thus, with the development of fiscal decentralization there is an increase in self-sufficiency of hromadas, which manifests itself in increased competitiveness, independence, resource availability and financial potential of regions, the development of investment and entrepreneurship in the territory, which ultimately will ensure the economic expansion of certain territories.

That is why the most effective option is when the population living in a particular territory is directly involved in the implementation of management functions in the region, which requires significant financial resources to ensure the implementation of management responsibilities. It is for this purpose that the process of decentralization was initiated in Ukraine in 2014. This is a complex and multi-component process, primarily related to fiscal decentralization. It is the basis for equitable replenishment of local budgets and its allocation.

\section{The main stages of decentralization in Ukriane}

European researchers foresee the following three elements of decentralization: fiscal decentralization, which includes the transfer of financial resources in the form of subsidies and tax authorities to subnational government units; administrative decentralization, which involves the transfer of functions performed by the central government to geographically remote administrative units; political decentralization with an emphasis on the transfer of authority and responsibility to elected bodies of local self-government (Scott, 2009; Gemmell, Kneller, Sanz, 2013).

Under the conditions of local self-government reform, through administrative and financial decentralization, the formation of local budgets, specifically their revenue side, is a task that needs to be solved as soon as possible. The implementation of the foundations of financial decentralization in the economic and administrative system of our state is supported and defined as key in the Concept of Local Government and Territorial Organization of Power Reform in Ukraine, approved by the Cabinet of Ministers of Ukraine on 18.06.2014 № 591-p (Pro skhvalennia Kontseptsii reformuvannia mistsevoho samovriaduvannia...).

Decentralization of fiscal powers is the main condition for ensuring the independence of local governments in the field of finance, and, conversely, strengthening the financial independence of local government should be seen as a result of financial decentralization (according to the legislation of Ukraine) (Podatkovyi kodeks Ukrainy, 2011)..

Thus, the reform was initiated, a sufficient number of methodological materials and roadmaps were developed, and the experience of European countries was systematized and used to some extent.Today it is possible to talk about the achievement of certain positive results.

The main results of the first stage of the reform of local self-government in Ukraine for the period 2014-2019 are systematized, outlining the main achievements.

So, the first steps of the reform answered the following question: "What is decentralization in practice? (it turned out that it is not just a process of transferring powers and creating local autonomy). In order for this process to be feasible and effective, conditions for development should be created. That is, the entire legal framework must be updated, significantly motivating territorial consolidation in order to effectively unite the efforts of citizens of villages, regions (oblasts), and districts (raions) in addressing the vital needs of this very hromada.

The financial support of local budgets, as it turned out, can also be effective and truly independent, autonomous of the state budget, if the managers of funds are residents of local hromadas. The data presented in Figure 1 suggests the positive results of the first steps of the five-year local self-governance reform, which prompts to move forward, that is, to the next, no less significant stage of decentralization, which continues even now in 2020-2021 (Figure 2).

For further effective reform it is necessary to carry out many important measures related to service in local government, namely training of specialists of a new formation, incentives to improve the image of local authorities and hromadas, it is also necessary to address the issue of changes in the Constitution of Ukraine and in the administrative organization of the country. All of these problems should be solved as soon as possible, otherwise the mechanism of reform will not ensure its successful advancement.

\section{Financial decentralization as a fundamental tool of local self-government}

Today it is clear to all that the central point and at the same time the problem for local self-governance 


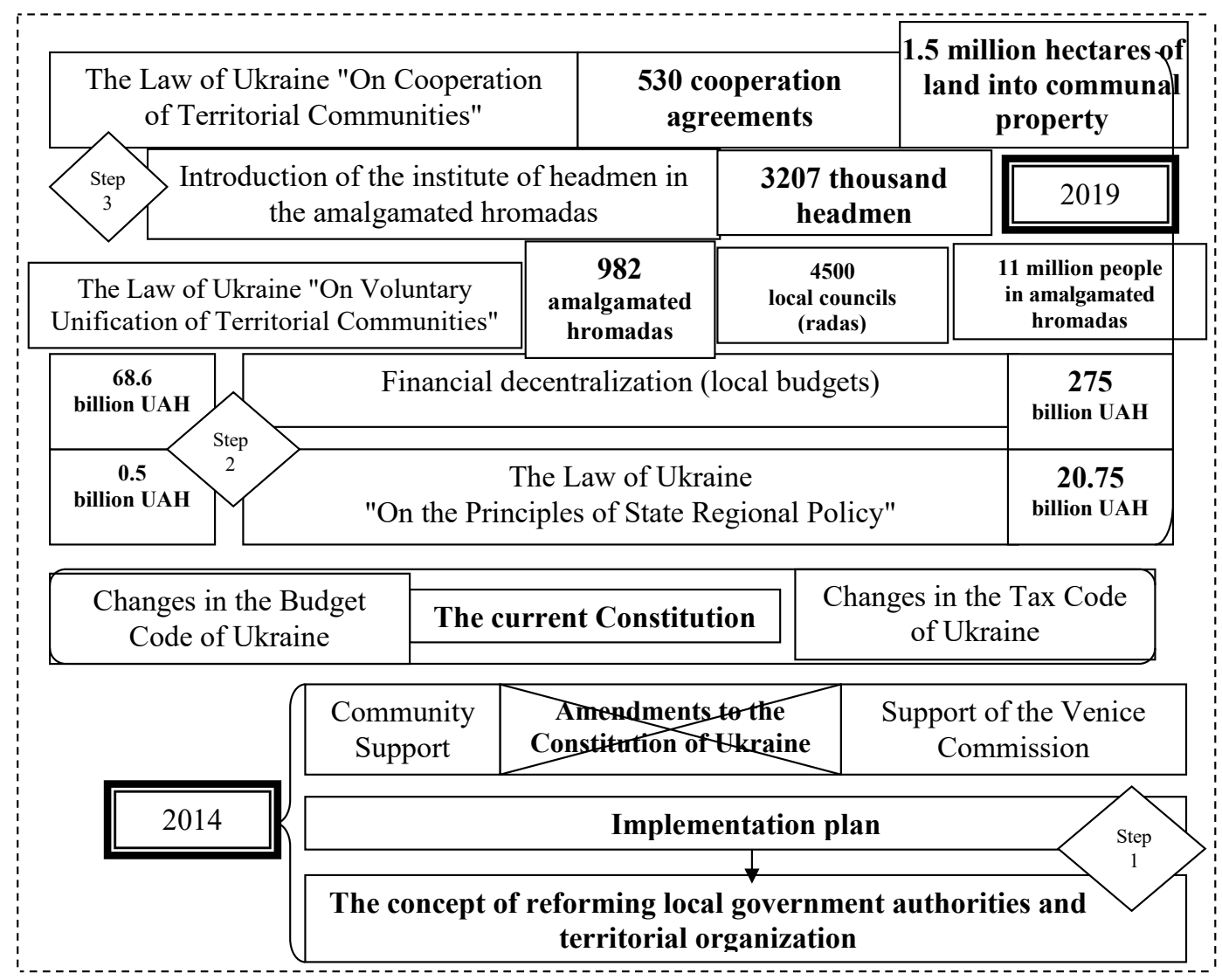

Figure 1. Results of Stage I of the Local Self-Government Reform in Ukraine, 2014-2019

is financial provision, that is, the formation of local budgets. Therefore, it is the problem of establishing local taxes and fees, as well as the development of local taxation as an instrument of local self-governance that deserves special attention. It is local taxes and fees that are tax payments that are fully received by the relevant local budget, and the establishment of which (although within a legally defined framework) is carried out by local self-government bodies.

For the state to effectively implement resource allocation and inter-budgetary relations, it is necessary to fully delegate not only accumulative, but also distributive and controlling responsibilities, and this step must be real, so that society has the opportunity to show its active civic position in addressing local issues, and the authorities would stop discrediting themselves with fake statements about the independence of hromadas.

The purpose of the fiscal decentralized approach is to distribute fairly the funds earned in the region for its direct development and to support projects that encourage entrepreneurs to provide and social

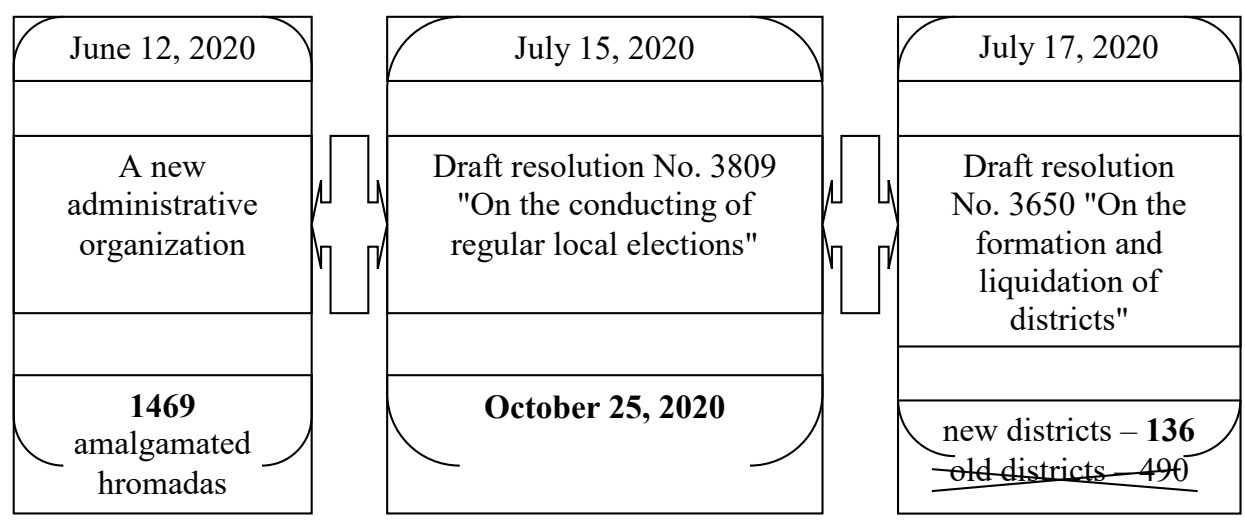

Figure 2. Significant dates of the second stage of the local self-government reform in Ukraine, 2020-2021 
component in the running of their own business. Such a balanced, cutting-edge expenditure budget policy will lead to stable development of the region and should contribute to the investment attractiveness of the individual hromada, which will ultimately lead to the balanced development of the whole country.

Consequently, the keynote of fiscal decentralization is the principle of fiscal equivalence, when the efficiency of a particular hromada is achieved through such a mechanism of formation of revenues to local budgets that the end consumer of public goods at the local level will be financially responsible for expenses, as well as their order, volume and priority, within the limits of taxes transferred to them. This order makes it possible to distribute the tax burden within the hromada, because its residents have the ability to regulate and control both the level of taxation and the level of their economic benefits, which is the financial leverage to encourage people to take part in the fiscal accumulation and provision of their own administrative-territorial region.

\section{Financial decentralization at the legislative level}

According to the developed strategy for decentralization in Ukraine, the budgetary legislation provides for the following changes, which will take effect on January 1, 2021:

1) the structure of sources of regional budget revenues remains unchanged;

2) 1,470 budgets of hromadas switched to direct inter-budgetary relations with the state budget;

3 ) personal income tax in the amount of $60 \%$ is credited to the budgets of hromadas;

4) district budgets are not included in the horizontal equalization system, in particular they will not receive a basic dotation;

5) district budgets will be formed from revenues from the use of district property, grants and subventions from other budgets (Reforma detsentralizatsii).

Such changes will lead to the most effective result, as long as they are carried out by competent bodies at the local level, that is, the functions and powers of village, settlement, and city councils (radas) have changed somewhat, so the development, review, and subsequent execution of local budgets in full should be carried out by newly formed municipalities, that is, it should prepare the entire package of documents in a short time, and then approve it. And it should be done without mistakes, clarifications and changes, after all, what rates of taxes and fees approved by local councils, with those will have to work the whole fiscal year, since in accordance with Ukrainian legislation the next six months no changes to any elements of local taxes and fees can be made (Paragraphs 4.1.9 Clause 4.1. Art. $4 \mathrm{TCU}$ ). In addition, according to Clause 4.5. of Art. 4 of the TCU, benefits for the expansion or modification of the existing order are also possible only from the next fiscal year (Podatkovyi kodeks Ukrainy, 2011).

In the Law of Ukraine "On the State Budget of Ukraine for 2021" it is noted that horizontal equalization will be implemented for 1,438 budgets of amalgamated hromadas and 24 budgets of regional ones, while basic subsidies and educational subventions for district budgets are not provided. Consequently, the basic part of the state budget will be formed only by village, city and town budgets, the funds of which can be raised only on contractual terms in the implementation of clearly defined economic or social and other projects. The following figure provides information on how hromada budgets are funded by the various financial sources (Zakon Ukrainy "Pro Derzhavnyi biudzhet Ukrainy na 2021 r.").

The structure of funding of hromada budgets in 2021 by different sources of funding was investigated. Based on the data of Figure 3 shows that $60 \%$ of individual income tax according to the legislation should be transferred to hromada budgets, and this is a very controversial issue among scientists, because the way in which the share of this tax should be sent to the budgets of local governments raises a number of controversial issues.

There are different mechanisms for collecting such a tax, namely: charging a part of the personal income tax to hromada budgets at the place of work of taxpayers or at the place of residence of taxpayers; some drafts propose to implement a proportional distribution of amounts of personal income tax revenues between residence and place of work of taxpayers; and, finally, there is an option to allow taxpayers to make an independent choice where tax on their income should be sent.

It may seem that too much attention is paid to this problem, but imagine that people registered in one place live and work in another, which means that a share of their income in the form of personal income tax is sent to the budget, where they do not live, and therefore do not use the benefits that are the equivalent of their payments.

This situation is seen as a systemic error that must be corrected, because this approach misrepresents the whole picture of fiscal equalization. If this issue is not resolved at the legislative level, it will ultimately lead to an understanding of the precariousness of the entire construction of fiscal decentralization, which will discredit all efforts to consolidate village and town councils (radas) in Ukraine. 
Tax on profits of companies and monetary institutions of public utilities

Rent payment for special use of forest resources of state importance

Rent payment for special use of water bodies of local importance

Rental payment for the use of mines and quarries for the extraction of minerals of national importance

Excise tax on sales of excisable goods by retailers

Fee for vehicle parking spaces

Tourist tax

Single Contribution

Payment for the placement of temporarily free funds of local budgets

Administrative fines and other sanctions

Payment for licenses for certain types of economic activities and certificates issued by executive bodies of local

councils and local executive authorities

Administrative fee for state registration of legal entities, individuals (entrepreneurs and public formations)

Payment for the provision of other administrative services

Administrative fee for state registration of rights to immovable property and its encumbrances

State duty

Rent payment for water bodies (their parts)

Concession payments for communal property

\begin{tabular}{|l|}
\hline Personal income tax \\
\hline Rent payment for special use of forest resources of state importance \\
\hline Rental payment for the use of mines and quarries for the extraction of minerals of national importance
\end{tabular}

Figure 3. Financing of hromada budgets in 2021 by various sources of funding

\section{Contradictions and ways to resolve them in the context of financial decentralization}

Observing the process of decentralization, it can be argued that this process does not last very easily, to solve this problem great efforts have been made, but these efforts will be in vain, because the personal income tax is more than $50 \%$ of the income of hromadas, that is, its revenue is the basis in this scheme.

To solve the problem in the system of charging tax on personal income it is proposed to study the theoretical aspects of public finance, as well as the experience of European countries with existing practices regarding the financing of local government through personal income tax.

Most importantly, after studying theoretical works on the subject of public finance, it was possible to establish that the more freedom in setting the rates of local taxes and fees is given to local governments, the greater the possibility of setting them at the level suggested by local residents, since the hromada will demand, with a high level of taxation, adequate quality provision for its vital needs and, in addition, accountability from local governments.

But in practice it works differently, because the administration of taxes such as value added tax, personal income tax and corporate income tax, which are the main sources of tax revenues of the budget, is more effectively performed by the state government, but the solution of social problems should be provided by local taxes and fees, that is, property tax mainly, which in volume is simply impossible. So, in practice there is a combination of local taxes and fees and interbudgetary transfers to cover the above-mentioned costs.

As a result of a comprehensive analysis of approaches to establishing the rate of personal income tax in European countries, it can be said with certainty that all of them determine its establishment not at the place of work, but at the place of residence of the payer.

Consequently, the idea of the whole decentralization reform is precisely that local government should serve those who elect it and, accordingly, reside in the territory of that hromada. Therefore, the charging of personal income tax to local budgets at the place of residence of the payer of this tax is the only possible step for a fair balance of financial opportunities of territorial units. Understanding such a legislative conflict, it is necessary to consider in more detail the operational consequences of such actions of the authorities. The government in this situation should come up with a proposal to reorganize as soon as possible at the legislative level the information and methodological system so that the Treasury would have the opportunity in 
Vol. 7 No. 4, 2021

Table 1

Reasons for setting the personal income tax rate by local authorities at the payer's place of residence

\begin{tabular}{|l|l|l|}
\hline \multicolumn{1}{|c|}{ Reason } & \multicolumn{1}{|c|}{ Explanation } & \multicolumn{1}{c|}{ Contradictions } \\
\hline $\begin{array}{l}\text { Personal income tax is about the total } \\
\text { income of citizens, not just wages and salaries }\end{array}$ & $\begin{array}{l}\text { Income can be derived from a variety of } \\
\text { sources other than the basic wage }\end{array}$ & $\begin{array}{l}\text { If the personal income tax is linked to the } \\
\text { place of work, the essence and basic idea of } \\
\text { the tax is lost }\end{array}$ \\
\hline $\begin{array}{l}\text { Distribution of competence between the } \\
\text { political and fiscal jurisdictions }\end{array}$ & $\begin{array}{l}\text { The funds of taxpayers that have made their } \\
\text { choice of political force should be distributed } \\
\text { precisely at the place of residence of the } \\
\text { electorate }\end{array}$ & $\begin{array}{l}\text { If people don't elect local authorities because } \\
\text { then't live there, that creates a situation } \\
\text { of "taxation without representation" }\end{array}$ \\
\hline $\begin{array}{l}\text { Provision of services to its residents by local } \\
\text { authorities }\end{array}$ & $\begin{array}{l}\text { People residing in a certain area } \\
\text { automatically want to improve living } \\
\text { conditions }\end{array}$ & $\begin{array}{l}\text { Obviously, where people work, it is also } \\
\text { necessary to create comfortable living } \\
\text { conditions, but it is no longer a question of } \\
\text { accumulation, but of spending }\end{array}$ \\
\hline
\end{tabular}

the next two or three years, using the rules, to set off part of the personal income tax at the place of residence of the person paying it.

And here begins the difficulties, from the very beginning of the distribution of responsibilities (that is, who and for what will be responsible in this complex process of reform), especially when it comes to the city of Kiev, because here the registration, place of residence and place of employment are generally three different places. This is where the authorities should delegate the Ministry of Finance of Ukraine to model and begin to implement, step by step, a new system for calculating personal income tax.

The Ministry of Finance of Ukraine, in turn, realizing the complexity of the process, creates an electronic format of relations, which will be accessible, convenient and reliable. The main thing in this scheme is to convince taxpayers that their timely and honest registration of residence is a guarantee of development of the territory in which they live, and that this is not another insidious plan against freedom of choice of residence. Many businesses already have this information about its employees, but the next step is to obtain a declaration of residence.

In such circumstances, the costs will be incurred precisely by enterprises (employers) to collect information about employees, but further the situation should be simplified for these enterprises. Following the idea of fiscal decentralization, the funds received from the taxpayer will be transferred by the treasury to the accounts of hromadas of such personal income tax payers through a unified information system.

Only after collecting data on the payment of personal income tax for six months, with the distribution of information on the place of residence and place of work of the payer, it will be possible to begin to build a model for the transformation and redistribution of the personal income tax under the new rules. Using the experience of developed countries, which have gone through all these stages of the formation of fiscal decentralization, it is only possible to predict what the consequences will be. Distribution and redistribution of personal income tax will be the main factor in the alignment of local budget relations in the regions and Kiev in the next few years (Lelechenko, Vasylieva, Kuibida, Tkachuk, 2017).

\section{Conclusions}

Accordingly, the situation during the transition period will provide another advantage for local governments is the opportunity to convey to their voters/taxpayers the importance of a reliable indication of residenceplace, and will also open new ways for government officials to think about solutions and problems of official registration of residence and peculiarities of the Ukrainian housing market.

The study defined the essence of fiscal decentralization in modern theory and practice as a fullscale procedure of changing the sources of expenditure and, accordingly, its funding on the granting autonomy and financial freedom to territorial communities, in order to increase the effect of transparency of the budget revenue generating process.

As part of the institutional analysis of the consequences of the decentralization of public finances, a number of suggestions can be made to solve the aforementioned issues of fiscal decentralization. First, it is necessary to improve the existing tax system in order to give local authorities the ability and opportunity to create budgets from its own sources in order to strengthen the autonomy of local authorities in providing the necessary resources. Second, it is necessary to stimulate territories that spread the trends of economic growth through reforming the mechanism of collecting personal income tax. It is also advisable to conduct further research in the aspect of land value taxation, taking into account the capabilities 
of hromadas and to propose optimal mechanisms of land value taxation. The implementation of the aforesaid proposals to fund the budgets of local governments and hromadas, in the end, should be the leverage on the structure of fiscal sources that will clearly indicate the need and value of all tax revenues at the local level. In conclusion, it is worth emphasizing that the process of decentralization is a multifaceted process, which covers not only the financial but also the social, political, and demographic situation in the country, so only if the authorities carry out a balanced policy of balancing the functioning and development of regions, it will be perceived by the population positively and for the purpose for which it was started.

\section{References:}

Scott, Z. (2009). Decentralisation, Local Development and Social Cohesion: An Analytical Review. University of Birmingham: Governance and Social Development Resource Centre. Available at: http://www.gsdrc.org/docs/ open/po60.pdf

Gemmell, N., Kneller, R., \& Sanz, A. (2013). Fiscal decentralization and economic growth: spending versus revenue decentralization. Economic Inquiry, 51(4), 1915-1931. Available at: http://www.socsci.uci.edu/ $\sim$ jkbrueck/course\%20readings/Econ\%20272B\%20readings/gemmell-kneller-sanz.pdf

Pro skhvalennia Kontseptsii reformuvannia mistsevoho samovriaduvannia ta terytorialnoi orhanizatsii vlady v Ukraini (2014) [Approval of the Concept of Local Self-Government Reform and Territorial Organization of Power in Ukraine]. Cabinet of Ministers of Ukraine; Regulation, Concept of 01.04.2014 № 333-p. (in Ukrainian)

Podatkovyi kodeks Ukrainy (2011) [Tax Code of Ukraine]. Available at: http://zakon.rada.gov.ua/cgibin/laws/ main.cgi?nreg=2755-17 (in Ukrainian)

"Reforma detsentralizatsii" Uriadovyi portal Ukrainy [«Reform of decentralization» Government portal of Ukraine]. Available at: https://www.kmu.gov.ua/diyalnist/efektivne-vryaduvannya/reforma-decentralizaciyi (in Ukrainian)

Zakon Ukrainy "Pro Derzhavnyi biudzhet Ukrainy na 2021 r." [The Law of Ukraine "On the State Budget of Ukraine for 2021"]. Available at: https://zakon.rada.gov.ua/laws/show/1082-20\#Text (in Ukrainian)

Lelechenko, A. P., Vasylieva, O. I., Kuibida, V. S., \& Tkachuk, A. F. (2017). Mistseve samovriaduvannia $\mathrm{v}$ umovakh detsentralizatsii povnovazhen [Local self-government in conditions of decentralization of powers]. Kyiv. (in Ukrainian) 